\title{
Assessment of the Severity of Anxiety and Depression Syndromes in Persons Undergoing Compulsory Treatment in a Psychiatric Hospital with Concomitant Pulmonary Tuberculosis
}

\author{
Vasyushkina Marina Aleksandrovna* \\ Russian Federation, Russia \\ Submission: February 15, 2018; Published: February 21, 2018 \\ *Corresponding author: Vasyushkina Marina Aleksandrovna, Federal State Institution "Orel psychiatric hospital (hospital) of specialized type \\ with intensive supervision" of the Ministry of Health of the Russian Federation, The city of Orel, Russia, Tel: +79202857393; \\ Email: marinaetoya@yandex.ru
}

\begin{abstract}
Abstact
Mental disorders such as anxiety and depression are common in tuberculosis patients. These conditions are especially expressed in persons under compulsory treatment. This is due to a number of reasons, such as the fact that a person has tuberculosis, tuberculosis intoxication, side effects of anti-tuberculosis drugs. Therefore, the provision of specialized medical care to these patients requires a comprehensive approach to this problem.
\end{abstract}

Keywords: Pulmonary tuberculosis; Mental disorders; Affective disorders

\section{Introduction}

Tuberculosis and mental disorders are socially significant diseases, and their combination burdens each other. It is proved that disorders of the Central nervous system function are accompanied by a decrease in the body's adaptation to the environment and lead to changes in homeostasis. Quite often TB patients are observed by a mental disorder affective spectrum, in particular anxiety and depression. These conditions are especially expressed in persons under compulsory treatment.

\section{Materials and methods}

The Aim of this study was to assess the severity of anxiety and depressive syndromes in persons who are on compulsory treatment in a psychiatric hospital, with concomitant pulmonary tuberculosis. It was examined 28 patients who are on compulsory treatment in Orel pbstin with various mental disorders: paranoid schizophrenia-20, mental retardation (oligophrenia) from mild to moderate-3, organic mental disorders-5. Patients from different regions of the country sent for compulsory treatment in OBSTIN court in connection with the recognition of the insane in respect of offences belonging to the category of grave and especially grave crimes. All patients had concomitant somatic pathology-pulmonary tuberculosis: $25 \%$ - pulmonary tuberculosis, 25\%-disseminated pulmonary tuberculosis, 25\% - focal pulmonary tuberculosis, and infiltrative and cirrhotic forms of tuberculosis $12.5 \%$ respectively. All patients were examined by the method of hospital rating scale of anxiety and depression (A. S. Zigmond, R. P. Snaith, 1983).

\section{Results and Discussion}

After the survey it was revealed that $80 \%$ of patients showed signs of clinically expressed anxiety and depression. 15\% were found to have subclinical expressed depression and anxiety. And only $5 \%$ of patients had no reliable symptoms of depression and anxiety. The results were due to various factors. First of all, all the patients were on compulsory treatment in a psychiatric hospital for a long time, that is, they were in isolation (more than 1 year). Secondly, $100 \%$ of the examined patients had one or another mental pathology, which is certainly the ground for the development of the above syndromes. And thirdly, all patients had concomitant somatic pathology in the form of pulmonary tuberculosis, which can provoke the development of anxiety and depression as follows:

a. Due to the fact of detection of tuberculosis,

b. Due to intoxication in the background of the tuberculosis process,

c. Due to side effects of anti-tuberculosis drugs.

At the same time, two patients in the last 12 months saw an exacerbation of the tuberculosis process, while the somatic state of the rest remained stable. 


\section{Conclusion}

Thus, pulmonary tuberculosis can both burden the existing mental disorders of the patient and provoke their appearance in mentally healthy people. Anxiety and depression syndrome are quite common in patients with pulmonary tuberculosis, especially with concomitant mental illness, under compulsory treatment, which should be taken into account in the provision of specialized medical care.

No Potential Conflict of Interest was Reported by the Author

Marina Aleksandrovna Vasyushkina occupies the position of Head of the Department that deals with patients with concomitant pulmonary tuberculosis, psychiatrist. He has participated in the following conferences: 2014: XVIIth World Congress of the World Association for Dynamic Psychiatry "Multidisciplinary approach treatment of mental disorders: myth or reality?" 2016: Annual Scientific-Practical conference with international participation on "Mental disorder of affective and schizophrenic spectrum: diagnostics, therapy and comorbidity". The author has so far made four scientific publications. She is a member of the Orel branch of the Russian Society of Psychiatrists.
Your next submission with Juniper Publishers will reach you the below assets

- Quality Editorial service

- Swift Peer Review

- Reprints availability

- E-prints Service

- Manuscript Podcast for convenient understanding

- Global attainment for your research

- Manuscript accessibility in different formats (Pdf, E-pub, Full Text, Audio)

- Unceasing customer service

Track the below URL for one-step submission https://juniperpublishers.com/online-submission.php 